\title{
Relative significance of phytoplankton, bacteria and plant detritus as carbon and nitrogen resources for the kelp bed filter-feeder Choromytilus meridionalis
}

\author{
L. J. Seiderer ${ }^{1} \&$ R. C. Newell ${ }^{2}$ \\ ${ }^{1}$ Benguela Ecology Programme, University of Cape Town, Rondebosch 7700, South Africa \\ ${ }^{2}$ Royal Society Senior Research Fellow, c/o Institute for Marine Environmental Research, Prospect Place, Plymouth PL1 3DH, \\ United Kingdom
}

\begin{abstract}
Standing stocks of phytoplankton on the West Coast of the Cape Peninsula, South Africa, show marked short-term variations, reaching maximal values of $8.9 \mu \mathrm{g}$ chlorophyll $\mathrm{a}^{-1}$ at the end of a downwelling phase when warm surface water of approximately $16^{\circ} \mathrm{C}$ impinges on the coast. Following a period of south-east winds, cold water of ca. $11^{\circ} \mathrm{C}$ or less upwells in the nearshore waters and chlorophyll a concentrations may fall within $24 \mathrm{~h}$ to $0.6 \mu \mathrm{g} \mathrm{l} \mathrm{l}^{-1}$ or less. At the same time, the standing stocks of bacteria ranged from a $0.4 \times 10^{6}$ cells $\mathrm{ml}^{-1}$ during strong upwelling pulses to $5.9 \times 10^{6}$ cells $\mathrm{ml}^{-1}$ during downwelling phases. (2) Total resource availability in the water column is

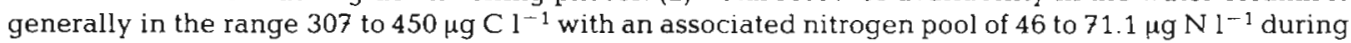
upwelling and downwelling phases. At the end of a downwelling phase the carbon represented by the phytoplankton component amounts to $>50 \%$ of the total particulate carbon in the water column and may dominate the resource as a whole. Bacteria, however, represent a carbon resource which is of comparable importance to the detrital component especially during periods of weak upwelling. Because of their relatively low C:N ratio of 3.5 compared with values as high as 18.9 for the detrital component, bacteria represent a nitrogen resource which may even exceed that of the phytoplankton under some conditions. (3) Estimates of the carbon consumption requirements of the black mussel Choromytilus meridionalis Krauss in relation to the potential yield from phytoplankton, bacterial and detrital pools suggest that a major utilisation of the detrital component would be required to meet the carbon demands even if phytoplankton were retained with a high efficiency. In contrast, the estimated nitrogen demands of 2.8 to $45.5 \mu \mathrm{g} \mathrm{N} \mathrm{h}-1$ at $12^{\circ} \mathrm{C}$, depending on shell length, could be met from the phytoplankton alone which could supply 12.5 to $127.4 \mu \mathrm{g} \mathrm{N} \mathrm{h}^{-1}$ at $100 \%$ efficiency. C. meridionalis does not therefore appear to require utilisation of bacteria to support its nutritional needs, a conclusion which is substantiated by the experimental work of others which suggests that particles in the bacterial size range are inefficiently retained by this mussel. (4) Phytoplankton and detrital pools are thus of importance as a carbon resource for bivalve consumers such as $C$. meridionalis. Bacteria, however, represent a nitrogen pool of comparable importance to the phytoplankton and which is likely to be of major significance to those filter-feeders which are capable of exploiting particles in the bacterial size range.
\end{abstract}

\section{INTRODUCTION}

The particle size spectrum which can be retained by filter-feeders has received widespread attention for several years (for review see Jørgensen 1975). In general it has been established that in bivalves particles down to approximately $4 \mu \mathrm{m}$ diameter are efficiently retained by the filtration system, although there are considerable differences between species, whether or not latero-frontal cilia are present, and according to habitat type, (Kirby-Smith 1976, Møhlenberg \& Riisgård 1978). Amongst the tunicates, smaller particles down to $1 \mu \mathrm{m}$ are capable of retention (Harbison \& McAlister 1979, Randløv \& Riisgård 1979) whilst some bivalves (Sorokin 1973, Wright et al. 1982) and several sponges appear to be capable of exploiting the bacterial size fraction (Claus et al. 1967, Reiswig 1971, 1975, Frost, 1978, Stuart \& Klumpp 1984). 
The quantitative significance of bacteria, phytoplankton and detrital material as food resources for such organisms is, however, difficult to assess without information not only on the retention efficiency but also the availability of the carbon and nitrogen supply and the demands of the consumer organisms. Most recent studies on the role of bacteria in the nutrition of deposit-feeders have reported that the quantity of bacteria available in the diet is substantially less than the carbon requirements of the consumer (Baker \& Bradnam 1976, Wetzel 1976, Jensen \& Siegismund 1980), the balance being probably met by direct utilisation of plant detritus as a carbon resource (Cammen 1977. $1980 a, b)$. Many invertebrates, particularly those living near to a detrital supply, are now known to be able to utilise plant detritus directly as a carbon resource (Elyakova 1972, Kristensen 1972, Newell et al. 1982, Seiderer et al. 1982; Stuart et al. 1982, Lucas \& Newell 1984). Hardly any data are available, however, on the supply of carbon available in the form of phytoplankton, bacteria and detritus as a resource for exploitation by filter-feeders

Intermittent pulses of phytoplankton-rich water occur during phases of downwelling on the west coast of the Cape Peninsula, and these alternate with pulses of cold, relatively plankton-depleted, upwelled water induced by south east winds (Andrews \& Hutchings 1980, Field et al. 1980, Barlow 1982) to produce a complex array of phytoplankton, bacteria and detritus whose fluxes may play an important part in the carbon and nitrogen balance of nearshore consumer communities (Wulff \& Field 1983). There is, however, even less information on the significance of these components as nitrogen resources for consumer organisms, and such values cannot be estimated easily from the carbon supply since in many cases the $C: N$ values depart significantly from the Redfield ratio. Because detrital material commonly has a $\mathrm{C}: \mathrm{N}$ ratio in excess of 15 , and sometimes as high as 20 , whereas phytoplankton has a $C: N$ ratio of approximately 6 and bacteria commonly have a $\mathrm{C}: \mathrm{N}$ ratio of 3.5 , the bacterial component may play a significant role in the supply of nitrogen to consumer organisms, even if their biomass or retention efficiency is relatively low (Field 1983, Newell \& Field 1983a, b, Newell 1984, Stuart \& Klumpp 1984)

The following work was therefore undertaken to obtain some realistic estimates of the carbon and nitrogen resources available for exploitation by the filterfeeding communities which characterise the rocky shores of the Cape Peninsula, South Africa, and which receive a regular input of detritus from kelp systems (Field et al. 1977, Newell et al. 1982).

Detailed information is presented on the relative significance of phytoplankton, bacteria and detritus as carbon and nitrogen resources on the east coast (False Bay) and during the pulsed upwelling/downwelling cycle on the west coast of the Cape Peninsula. Some estimates are made of the significance of such components as nutritional resources for the black mussel Choromytilus meridionalis Krauss, which is a common component of the filter-feeding community. The data can also be combined with information on filtration efficiency and biomass to estimate the quantitative significance of phytoplankton, bacteria and detritus for the nearshore community as a whole.

\section{MATERIAL AND METHODS}

Sampling procedure. Routine sampling was carried out at Bloubergstrand and Oudekraal on the west coast, and at Bailey's Cottage which is in False Bay on the east coast of the Cape Peninsula, South Africa. The water temperature at the time of sampling was recorded, and then water samples taken for chlorophyll $a$, bacterial numbers and particulate organic carbon and nitrogen. Samples for bacteria were fixed immediately in $0.5 \%$ glutaraldehyde and analysed in the laboratory (see below). The water samples for chlorophyll $a$ and particulate organic carbon and nitrogen analysis were taken back to the laboratory in vacuum flasks for immediate filtration.

Chlorophyll a. Aliquots of $800 \mathrm{ml}$ seawater were filtered under vacuum through a $4.7 \mathrm{~cm}$ diameter $\mathrm{GF} / \mathrm{F}$ filter. The filters were subsequently folded, wrapped in aluminium foil, and frozen at $-14^{\circ} \mathrm{C}$ until required. They were then ground with a Teflon rod in $12 \mathrm{ml} 90 \%$ $\mathrm{v} / \mathrm{v}$ acetone, sonicated for $30 \mathrm{~min}$ and centrifuged at $7000 \times \mathrm{g}$ for $15 \mathrm{~min}$. The supernatant was carefully removed and read at $750,664,647$ and $630 \mathrm{~nm}$ on a Beckman Model 26 spectrophotometer against $90 \% \mathrm{v} /$ $\mathrm{v}$ acetone. After subtraction of blank values, the chlorophyll a concentrations were expressed as $\mu \mathrm{g}^{-1}$ of seawater filtered (Jeffrey \& Humphrey 1975).

The carbon equivalent of chlorophyll $a$ is commonly estimated from chl $a \times 100$ (Stickland 1972). This value is, however, known to vary considerably, ratios of carbon : chl a of 70 being representative of rapidly growing phytoplankton (Dr. L. Hutchings, Sea Fisheries Research Institute, Roggebaai, South Africa, pers. comm.). We have therefore measured the carbon : chl a ratio in seawater samples during a complete upwelling : downwelling cycle between 16 th and 22 nd March 1983 (see also Seiderer 1983). The ratio was found to increase from 90 on 16 th March, 110 on 17 th March to 122 on 18 th March as an increased proportion of inert detrital POC entered the water column. It then declined to 107 on 19th March, 62 on 20th and 60 on 22nd March as the phytoplankton attained a rapid rate 
of growth. For the purposes of our estimation of the carbon equivalent of the phytoplankton standing stocks, we have taken a phytoplankton carbon : chlorophyll a ratio of $60: 1$ as representative of the actively growing phytoplankton available in the water column during downwelling conditions and during much of the later phases of upwelling. The nitrogen equivalent of the phytoplankton standing stocks was estimated from a C:N ratio of 6.6:1 (Seiderer et al. 1984, from Bailey pers. comm.). The protein equivalent was obtained from $\mathrm{N} \times 6.25$ on a basis of $16 \%$ nitrogen content in protein.

Bacteria. Numbers of micro-organisms were determined following the acridine orange direct counting method (Hobbie et al. 1977, Daley 1979, Linley et al. 1981, Linley 1983). All samples for microbial counts were placed in autoclaved scintillation vials using a sterile syringe and fixed in glutaraldehyde to give a final concentration of $0.5 \%$. They were then stored in the dark at $5^{\circ} \mathrm{C}$ until use.

Polycarbonate Nuclepore membranes $(25 \mathrm{~mm}$ diameter, $0.2 \mu \mathrm{m}$ pore size) were stained before use by soaking overnight in a solution of $2 \mathrm{~g}$ Irgalan Black in $11 \mathrm{ml} 2 \%$ acetic acid, rinsed in distilled water and covered until use. Samples were stained with $10 \mathrm{mg} \mathrm{l}^{-1}$ acridine orange (Strugger 1949) by incubating known volumes of sample with an equal volume of acridine orange in a sterile test tube for at least $3 \mathrm{~min}$. The sample was then filtered through the stained Nuclepore filter, applying a vacuum of $<0.8 \mathrm{~atm}$. Subsequently, the filter was immediately placed on a drop of non-fluorescent low viscosity Nikon immersion oil on a glass slide, before adding a second drop of oil and cover slip. In general at least 300 cells were counted per slide preparation at a density of 15 to 20 cells per field. Bacterial density was finally calculated from the expression (Linley 1983):

Bacterial density $(\mathrm{N})=\frac{\mathrm{S} \times 10^{6} \times \mathrm{n}}{\mathrm{s} \times \mathrm{v}}$ cells $\mathrm{ml}^{-1}$

where: $\mathrm{S}=$ working surface area of filter $\left(\mathrm{mm}^{2}\right)_{;} \mathrm{n}=$ mean number of cells per field; $s=$ area of microscope field $\left(\mu \mathrm{m}^{2}\right) ; \mathrm{v}=$ volume of sample filtered (ml). Direct visual estimates (DVE) of biovolume can then be made from the distribution of size and shape categories in the sample (Zimmermann \& Meyer-Reil 1974, Zimmermann 1977, Linley 1983). In general, small cocci of mean volume $0.067 \mu^{3}$ predominated in natural seawater samples, but these tend to be replaced by large rods of up to $0.872 \mu \mathrm{m}^{3}$ in experimental incubations (Linley et al. 1981, Linley 1983).

Estimates of bacterial biomass were then calculated using the expression:

Wet biomass $=(\mathrm{N} \times \mathrm{wmcv} \times \mathrm{SG}) / 10^{6} \mathrm{mg} \mathrm{l}^{-1}$ where: $\mathrm{N}=$ mean number of cells $\mathrm{ml}^{-1}\left(\times 10^{6}\right)$; wmcv $=$ weighted mean cell volume $\left(\mu \mathrm{m}^{3}\right) ; \mathrm{SG}=$ assumed specific gravity of 1.1 (Luria 1960)

Finally, a value of carbon was obtained from $0.1 \times$ wet biomass since it is the mean of values cited in the literature which range from 0.079 (Ferguson \& Rublee, 1976) to 0.15 (Hagström et al. 1979, see also Troitsky \& Sorokin 1967). A C:N ratio of 3.5:1 (from Seiderer et al. 1984) was used to calculate the nitrogen equivalent of bacterial carbon, and this was multiplied by 6.25 to give bacterial protein.

CHN-analysis. Particulate organic carbon and nitrogen analyses were carried out on samples of seawater which had been initially filtered through a $200 \mu \mathrm{m}$ mesh to remove larger particulate material. A measured volume of 100 to $1000 \mathrm{ml}$, depending on particulate load, was filtered under a vacuum of $<12 \mathrm{~cm} \mathrm{Hg}$ through $25 \mathrm{~m}$ Whatman GF/F glass fibre filters which had been pre-ashed at $400^{\circ} \mathrm{C}$ for $6 \mathrm{~h}$. The filters were stored at $-20^{\circ} \mathrm{C}$ and then oven dried at $55^{\circ} \mathrm{C}$ prior to analysis with a Heraeus CHN-Mikro universal combustion analyser calibrated with cyclohexane (Monar 1972). Detrial carbon and nitrogen were obtained by difference between the total carbon and nitrogen and the sum of bacterial and phytoplankton carbon and nitrogen.

\section{RESULTS}

\section{Carbon and nitrogen resources in coastal waters of the Cape Peninsula}

\section{Standing stocks of phytoplankton}

The standing stocks of phytoplankton and the primary production in the coastal waters of the Cape Peninsula have been studied by Brown (1981), and more recently near to kelp beds by Carter (1982). The chlorophyll a concentrations recorded by Brown (1981) at Robben Island in Table Bay and at Oudekraal are shown together with values recorded by Seiderer (1983) in Table 1. Also shown is a series of measurements during upwelling and downwelling phases on the west coast at Oudekraal and Bloubergstrand, and under the warmer water conditions at Dalebrook (from Cliff 1982) and Bailey's Cottage in False Bay on the east coast.

The most obvious feature of these data is that the chlorophyll a values can be very variable indeed, ranging from as high as $8.9 \mu \mathrm{g} \mathrm{l}^{-1}$ in summer (21 Jan 84 ) but declining within a day to $0.4 \mu \mathrm{g}^{-1}$ on $22 \mathrm{Feb} 84$ at Oudekraal. The data for both stations at Oudekraal and Bloubergstrand show some quite characteristic features of the upwelling/downwelling cycle on the west coast of the Cape Peninsula. At Oudekraal, for 
Table 1. Phytoplankton as a carbon and nitrogen resource in coastal waters of the Cape Peninsula. Chlorophyll a values ( $\mu$ g $\mathbf{l}^{-1}$ ) have been converted to phytoplankton carbon using a ratio of $60: 1$ (values of carbon:chlorophyll a recorded during a downwelling phase by Seiderer 1983). The source of chlorophyll a data is shown in the final column. Also shown is temperature of the water and whether this corresponded with upwelling (U) or downwelling (D) on the west coast

\begin{tabular}{|c|c|c|c|c|c|c|c|}
\hline & $T\left(C^{\circ}\right)$ & $\mathrm{U} / \mathrm{D}$ & $\begin{array}{c}\text { Clor } a \\
\left(\mu \mathrm{g} \mathrm{l}^{-1}\right)\end{array}$ & $\begin{array}{l}\text { Carbon } \\
\left(\mu \mathrm{g} \mathrm{l}^{-1}\right)\end{array}$ & $\begin{array}{c}\text { Nitrogen } \\
\left(\mu \mathrm{gl}^{-1}\right)\end{array}$ & $\begin{array}{l}\text { Protein } \\
\left(\mu \mathrm{g} \mathrm{l}^{-1}\right)\end{array}$ & Source \\
\hline \multicolumn{8}{|c|}{ (a) West coast } \\
\hline \multicolumn{8}{|c|}{ Robben Island } \\
\hline Oudekraal & - & - & 4.3 & 258.0 & 39.1 & 244.4 & Brown (1981) \\
\hline 21. 2.84 & 14 & $\mathrm{D}$ & 8.9 & 534.0 & 80.9 & 505.7 & Present study \\
\hline 22.2 .84 & 16 & $\mathrm{D}$ & 0.4 & 22.8 & 3.5 & 21.6 & Present study \\
\hline 23. 2.84 & 15.5 & $\mathrm{D}$ & 3.4 & 204.0 & 30.9 & 193.2 & Present study \\
\hline 9. 3.84 & 11 & $\mathrm{U}$ & 0.6 & 34.2 & 5.2 & 32.4 & Present study \\
\hline \multicolumn{8}{|c|}{ Bloubergstrand } \\
\hline 16. 4.83 & 12.5 & $\mathrm{U}$ & 3.6 & 214.8 & 32.6 & 203.4 & Seiderer (1983) \\
\hline 17.4 .83 & 11.5 & $\mathrm{U}$ & 2.0 & 122.4 & 18.6 & 115.9 & Seiderer (1983) \\
\hline 18. 4. 83 & 12 & $\mathrm{U}$ & 1.5 & 87.0 & 13.2 & 82.4 & Seiderer (1983) \\
\hline 19.4 .83 & 10 & $\mathrm{U}$ & 2.1 & 126.0 & 19.1 & 119.3 & Seiderer (1983) \\
\hline 20.4 .83 & 11 & $\mathrm{U}$ & 3.9 & 232.2 & 35.2 & 220.0 & Seiderer (1983) \\
\hline 22. 4.83 & 13 & $\mathrm{U}$ & 2.5 & 148.2 & 22.5 & 140.0 & Seiderer (1983) \\
\hline 20.2 .84 & 15 & $\mathrm{D}$ & 0.4 & 23.4 & 3.6 & 22.2 & Present study \\
\hline 21.2 .84 & 14.5 & $\mathrm{D}$ & 0.8 & 50.4 & 7.6 & 47.7 & Present study \\
\hline 22. 2.84 & 16 & $\mathrm{D}$ & 4.6 & 277.8 & 42.1 & 263.1 & Present study \\
\hline 6. 3.84 & 16 & $\mathrm{D}$ & 5.9 & 357.0 & 54.1 & 338.1 & Present study \\
\hline 9. 3.84 & 13 & $\mathrm{U}$ & 1.2 & 71.4 & 10.8 & 67.6 & Present study \\
\hline \multicolumn{8}{|l|}{ (b) East coast } \\
\hline Dalebrook & - & - & 4.0 & 240.0 & 36.4 & 227.5 & Cliff (1982) \\
\hline \multicolumn{8}{|c|}{ Bailey's Cottage } \\
\hline 17. 1.84 & - & - & 4.2 & 254.4 & 38.5 & 240.6 & Present study \\
\hline 24.1 .84 & 21 & - & 1.3 & 75.0 & 11.4 & 71.3 & Present study \\
\hline 7. 2.84 & 15 & - & 1.3 & 78.0 & 11.8 & 73.8 & Present study \\
\hline 20. 2. 84 & 21 & - & 3.4 & 201.0 & 30.5 & 190.3 & Present study \\
\hline 21.2 .84 & 19 & - & 0.0 & 0 & 0 & 0 & Present study \\
\hline
\end{tabular}

example, it can be seen that sampling started on 21 Feb 84 in the middle of a downwelling cycle when phytoplankton-rich surface water occurred near to the coast. Then in the subsequent $3 \mathrm{~d}$ subsurface water was driven offshore by southeast winds and cold water at $11^{\circ} \mathrm{C}$ upwelled near to the coast. At this stage chlorophyll $a$ values fell to the minimum of $0.6 \mu \mathrm{g} \mathrm{l}^{-1}$.

In much the same way at Bloubergstrand standing stocks of phytoplankton built up from $0.4 \mu \mathrm{g} \mathrm{l}^{-1}$ on 20 Feb 84 at the beginning of a downwelling phase to $5.9 \mu \mathrm{g} 1^{-1}$ prior to a period of south east winds on 09 Mar 84 when the water temperature began to fall again as upwelled water surfaced near the coast. At other times, during March and April 1983, rather weak southeasterly winds resulted in few clear bouts of upwelling and standing stocks of chlorophyll a ranged from 1.5 to $3.6 \mu \mathrm{g} \mathrm{l}^{-1}$.

At Bailey's Cottage in False Bay, temperatures are considerably higher than on the west coast, but at this site variations in standing stocks of chlorophyll a are also associated with onshore/offshore patterns in the prevailing winds. Carbon, nitrogen and protein equivalents have been estimated from the chlorophyll a values (p. 128) and allow some comparisons to be made between the contribution of phytoplankton and bacteria to the carbon and nitrogen pool of nearshore waters.

\section{Standing stocks of bacteria}

The standing stocks of bacteria have been studied in the coastal waters of the Cape Peninsula by Mazure (1978), Mazure \& Field (1980), Cliff (1982) and Linley et al. (1983), although few details are available for upwelling and downwelling cycles on the west coast.

Table 2 shows the bacterial numbers recorded at Oudekraal and Bloubergstrand during upwelling and downwelling conditions, as well as values for the water column in False Bay at Dalebrook (from Cliff 1982) and at Bailey's Cottage. It is apparent that bacterial numbers are relatively high, ranging from 0.4 to $6.3 \times 10^{6}$ cells $\mathrm{ml}^{-1}$ and that as a carbon and nitrogen 
Table 2. Bacteria as a carbon and nitrogen resource in coastal waters of the Cape Peninsula. Bacterial numbers (no. $\mathrm{ml}^{-1} \times 10^{6}$ ) have been converted to wet biomass from $(\mathrm{N} \times$ wmcv $\times \mathrm{SG}) 10^{6} \mathrm{mg} \mathrm{l}^{-1}$; where $\mathrm{N}=$ mean number of cells $\mathrm{ml}^{-1}$; wmcv $=$ weighted mean cell volume $\left(\mu \mathrm{m}^{3}\right)$; $\mathrm{SG}=$ specific gravity of $1.1 \mathrm{~g} \mathrm{~cm}^{-1}$ (Luria 1960). The source of data for bacterial numbers is shown in the final column. Also shown is upwelling (U) or downwelling (D) on the West coast

\begin{tabular}{|c|c|c|c|c|c|c|c|c|}
\hline Site & $\begin{array}{c}\mathrm{T} \\
\left({ }^{\circ} \mathrm{C}\right)\end{array}$ & $\mathrm{U} / \mathrm{D}$ & $\begin{array}{l}\text { No } \mathrm{ml}^{-1} \\
\times 10^{6}\end{array}$ & $\begin{array}{c}\text { Wet } \\
\text { Biomass } \\
\left(\mu g \mathrm{I}^{-1}\right)\end{array}$ & $\begin{array}{l}\text { Carbon } \\
\left.(\mu g)^{-1}\right)\end{array}$ & $\begin{array}{c}\text { Nitrogen } \\
\left.(\mu g]^{-1}\right)\end{array}$ & $\begin{array}{l}\text { Protein } \\
\left(\mu g l^{-1}\right)\end{array}$ & Source \\
\hline \multicolumn{9}{|l|}{$\begin{array}{l}\text { (a) West coast } \\
\text { Oudekraal }\end{array}$} \\
\hline Upwelling & & $\mathrm{U}$ & 0.4 & 81.4 & 8.1 & 2.3 & 14.6 & Seiderer et al. (1984) \\
\hline Downwelling & & $D$ & 3.0 & 610.5 & 61.1 & 17.4 & 109.0 & Seiderer et al. (1984) \\
\hline 21.2 .84 & 14 & $\mathrm{D}$ & 5.9 & 1043.7 & 104.4 & 29.8 & 186.4 & Present study \\
\hline 22.2 .84 & 16 & $\mathrm{D}$ & 5.8 & 852.0 & 85.2 & 24.3 & 152.1 & Present study \\
\hline 23. 2.84 & 15.5 & $\mathrm{D}$ & 6.3 & 776.6 & 77.7 & 22.2 & 138.7 & Present study \\
\hline 9.3 .84 & 11 & $\mathrm{U}$ & 4.0 & 566.7 & 56.7 & 16.2 & 101.2 & Present study \\
\hline \multicolumn{9}{|c|}{ Bloubergstrand } \\
\hline 16.4 .83 & 12.5 & $\mathrm{U}$ & 2.7 & 547.4 & 54.7 & 15.6 & 97.8 & Seiderer (1983) \\
\hline 17. 4.83 & 11.5 & U & 2.3 & 470.1 & 47.0 & 13.4 & 83.9 & Seiderer (1983) \\
\hline 18.4 .83 & 12 & $\mathrm{U}$ & 2.7 & 547.4 & 54.7 & 15.6 & 97.8 & Seiderer (1983) \\
\hline 19. 4.83 & 10 & $\mathrm{U}$ & 2.3 & 470.1 & 47.0 & 13.4 & 131.7 & Seiderer (1983) \\
\hline 20.4 .83 & 11 & $\mathrm{U}$ & 2.8 & 563.7 & 56.4 & 16.1 & 149.7 & Seiderer (1983) \\
\hline 22.4 .83 & 13 & $U$ & 3.6 & 734.6 & 73.5 & 21.0 & 195.0 & Seiderer (1983) \\
\hline 20.2 .84 & 15 & $\mathrm{D}$ & 4.3 & 820.9 & 82.1 & 23.5 & 146.6 & Present study \\
\hline 21.2 .84 & 14.5 & $\mathrm{D}$ & 3.6 & 624.4 & 62.4 & 17.8 & 111.5 & Present study \\
\hline 22.2 .84 & 16 & $\mathrm{D}$ & 2.8 & 577.3 & 57.7 & 16.4 & 102.7 & Present study \\
\hline 6.3 .84 & 16 & $\mathrm{D}$ & 3.7 & 717.1 & 71.7 & 20.5 & 128.1 & Present study \\
\hline 9. 3.84 & 13 & $\mathrm{U}$ & 3.8 & 761.6 & 76.2 & 21.8 & 136.0 & Present study \\
\hline \multicolumn{9}{|l|}{ (b) East coast } \\
\hline Dalebrook & - & - & 0.8 & 162.8 & 16.3 & 4.7 & 29.1 & Cliff (1982) \\
\hline \multicolumn{9}{|c|}{ Bailey's Cottage } \\
\hline 24.1 .84 & 21 & - & 2.5 & 674.5 & 67.5 & 19.3 & 120.5 & Present study \\
\hline 7. 2.84 & 15 & - & 1.9 & 665.7 & 66.6 & 19.0 & 118.9 & Present study \\
\hline 20. 2.84 & 21 & - & 6.2 & 1114.9 & 111.5 & 31.9 & 199.1 & Present study \\
\hline 21. 2.84 & 19 & - & 5.4 & 834.6 & 83.5 & 23.9 & 149.0 & Present study \\
\hline
\end{tabular}

resource, the bacterial biomass can represent a significant proportion of the total available in the water column. There is also some evidence of parallel variation in bacterial numbers to that noted for the standing stocks of chlorophyll a. At Oudekraal, for example, minimal values for bacterial numbers of $0.4 \times 10^{6}$ cells $\mathrm{ml}^{-1}$ were recorded during strong upwelling conditions by Seiderer et al. (1984) whilst maximal numbers of $6.3 \times 10^{6}$ cells $\mathrm{ml}^{-1}$ were recorded on 23 Feb 84 following a downwelling pulse. Again, at Bloubergstrand weak upwelling conditions are associated with relatively uniform bacterial numbers of 2.3 to $3.6 \times 10^{6}$ cells $\mathrm{ml}^{-1}$ whilst rather higher values of up to $4.3 \times 10^{6}$ cells $\mathrm{ml}^{-1}$ were recorded between 20 Feb 84 and $6 \mathrm{Mar}$ 84 during downwelling conditions.

Carbon, nitrogen and protein equivalents of the mibrobial biomass are also shown in Table 2; they allow some estimates of the relative significance of bacteria as a food resource compared with the phytoplankton and detrital components.

\section{Detritus as carbon and nitrogen resource}

The carbon and nitrogen represented by the detrital component can be estimated from the difference between the total particulate carbon and nitrogen in the water column and the sum of that in phytoplankton and bacteria.

Values for the carbon equivalent of phytoplankton, bacteria, total carbon and, by difference, detrital carbon are shown in Table 3. From this it is clear that towards the end of a downwelling phase, when phytoplankton is at its maximum, the carbon represented by phytoplankton generally amounts to $>50 \%$ of the total particulate carbon in the water column and may dominate the carbon resource as a whole. At the same time, the bacteria represent a carbon resource which is of similar importance to the detrital carbon, especially during downwelling phases. During much of the relatively weak upwelling period between $16 \mathrm{Apr} 83$ and 22 Apr 83, for example, the bacterial carbon amounted 
Table 3. Relative significance of phytoplankton, bacteria and detritus as a carbon resource in coastal waters of the Cape Peninsula. Data for phytoplankton and bacteria summarized from Tables 1 \& 2 . The total carbon measured by CHN-analysis is also shown as well as the detrital carbon obtained by difference [Total carbon-(phytoplankton + bacterial carbon)]. Water temperatures and occurrence of upwelling (U) and downwelling (D) phases at the West Coast sites are also listed

\begin{tabular}{|c|c|c|c|c|c|c|c|}
\hline Site & $\begin{array}{c}\mathrm{T} \\
\left({ }^{\circ} \mathrm{C}\right)\end{array}$ & $\mathrm{U} / \mathrm{D}$ & $\begin{array}{c}\mathrm{A} \\
\text { Phytoplankton } \\
\left(\mu \mathrm{g} \mathrm{C}^{-1}\right)\end{array}$ & $\begin{array}{c}\mathrm{B} \\
\text { Bacteria } \\
\left(\mu g \mathrm{C}^{-1}\right)\end{array}$ & $\begin{array}{c}A+B \\
\left(\mu g C^{-1}\right)\end{array}$ & $\begin{array}{c}\text { Total } \\
\text { carbon } \\
\left(\mu g l^{-1}\right)\end{array}$ & $\begin{array}{c}\text { Detrital carbon } \\
\text { Total }-(\mathrm{A}+\mathrm{B}) \\
\left(\mu \mathrm{gl}^{-1}\right)\end{array}$ \\
\hline \multicolumn{8}{|c|}{ (a) West coast } \\
\hline \multicolumn{8}{|l|}{ Oudekraal } \\
\hline 21.2 .84 & 14 & $\mathrm{D}$ & 534.0 & 104.4 & 638.4 & 730 & 91.6 \\
\hline 22.2 .84 & 16 & $\mathrm{D}$ & 22.8 & 85.2 & 108.0 & 446 & 338.0 \\
\hline 23.2 .84 & 15.5 & $\mathrm{D}$ & 204.0 & 77.7 & 281.7 & 208 & - \\
\hline 9. 3. 84 & 11 & $\mathrm{U}$ & 34.2 & 56.7 & 90.9 & 53 & - \\
\hline \multicolumn{8}{|c|}{ Bloubergstrand } \\
\hline 16. 4.83 & 12.5 & $\mathrm{U}$ & 214.8 & 54.7 & 269.5 & 320 & 50.5 \\
\hline 17.4 .83 & 11.5 & $\mathrm{U}$ & 122.4 & 47.0 & 169.4 & 220 & 50.6 \\
\hline 18. 4.83 & 12 & $\mathrm{U}$ & 87.0 & 54.7 & 141.7 & 190 & 48.3 \\
\hline 19. 4.83 & 10 & $\mathrm{U}$ & 126.0 & 47.0 & 173.0 & 220 & 47.0 \\
\hline 20.4 .83 & 11 & $\mathrm{U}$ & 232.2 & 56.4 & 288.6 & 240 & - \\
\hline 22.4 .83 & 13 & U & 148.2 & 73.5 & 221.7 & 160 & - \\
\hline 20.2 .84 & 15 & $\mathrm{D}$ & 23.4 & 82.1 & 105.5 & 388 & 282.5 \\
\hline 21. 2.84 & 14.5 & $\mathrm{D}$ & 50.4 & 62.4 & 112.8 & 391 & 278.2 \\
\hline 22. 2. 84 & 16 & $\mathrm{D}$ & 277.8 & 57.7 & 335.5 & 315 & - \\
\hline 6. 3. 84 & 16 & $\mathrm{D}$ & 357.0 & 71.7 & 428.7 & 650 & 221.3 \\
\hline 9. 3.84 & 13 & U & 71.4 & 76.2 & 147.6 & 950 & 802.4 \\
\hline \multicolumn{8}{|c|}{ (b) East coast } \\
\hline \multicolumn{8}{|c|}{ Bailey's Cottage } \\
\hline 24.1 .84 & 21 & - & 75.0 & 67.5 & 142.5 & 111.6 & - \\
\hline 7. 2.84 & 15 & - & 78.0 & 66.6 & 144.6 & 473.2 & 328.6 \\
\hline 20.2 .84 & 21 & - & 201.0 & 111.5 & 312.5 & 353.0 & 40.5 \\
\hline 21.2 .84 & 19 & - & 0 & 83.5 & 83.5 & 168.0 & 84.5 \\
\hline
\end{tabular}

to 47 to $73 \mu \mathrm{g} \mathrm{l}^{-1}$ whilst the detrital supply amounted to 47 to $50.5 \mu \mathrm{g} 1^{-1}$. At the same time, phytoplankton accounted for 87 to $232 \mu \mathrm{g} \mathrm{Cl} \mathrm{C}^{-1}$ and thus amounted to 2 to $3 \times$ that of the bacterial or detrital components.

Nitrogen equivalents of the standing stocks of phytoplankton, bacteria and detritus are summarised in Table 4 . In this case a rather different picture emerges for the relative significance of each component. Because of their relatively low C:N ratio, the bacteria represent a nitrogen resource of an importance comparable to that of the phytoplankton, especially during upwelling phases.

At the peak of a downwelling phase, however, the nitrogen in phytoplankton is approximately double that in the bacteria whose absolute significance as a nitrogen resource is broadly similar during the upwelling/downwelling cycle. The nitrogen component of the detrital supply is generally low, especially during upwelling phases, suggesting that most of the nitrogen in the nearshore environment is locked up in freeliving bacteria and phytoplankton rather than in bacteria attached to the detrital material. During downwelling phases, however, there is an increase in the nitrogen content of the detrital material, perhaps representing freshly decomposing phytoplankton carried in with the downwelling water.

Mean values for carbon and nitrogen in phytoplankton, bacteria and detritus are shown in Table 5 as well as the $C: N$ ratio for the detrital component. The total resource $\left(\mu \mathrm{g} \mathrm{l}^{-1}\right)$ and its $\mathrm{C}: \mathrm{N}$ ratio are also shown. It will further be noted that the carbon supply in the water column is likely to vary from 307 to $458 \mu \mathrm{g} \mathrm{l}^{-1}$ during upwelling and downwelling phases, with an associated nitrogen variation of 46.2 to $71.1 \mu \mathrm{g} \mathrm{l}^{-1}$.

\section{Carbon and nitrogen requirements of the mussel Choromytilus meridionalis}

\section{Carbon requirements in relation to potential yield}

One measure of the significance of the potential carbon resources in the water column is to calculate the carbon requirements of key consumer organisms and to determine to what extent the resource in the water filtered could meet the estimated carbon demand. 
Table 4. The relative importance of phytoplankton, bacteria and detritus as a nitrogen resource in coastal waters of the Cape Peninsula. Data for phytoplankton and bacteria summarized from Tables $1 \& 2$. The total nitrogen measured by CHN-analysis is also shown as well as the detrital nitrogen obtained by difference [Total Nitrogen - (phytoplankton + bacterial nitrogen)]. The water temperatures and the occurrence of upwelling (U) and downwelling (D) phases on the West Coast sites are also shown

\begin{tabular}{|c|c|c|c|c|c|c|c|}
\hline Site & $\begin{array}{c}\mathrm{T} \\
\left({ }^{\circ} \mathrm{C}\right)\end{array}$ & $\mathrm{U} / \mathrm{D}$ & $\begin{array}{c}\text { A } \\
\text { Phytoplankton } \\
\left(\mu \mathrm{g} \mathrm{I}^{-1}\right)\end{array}$ & $\begin{array}{c}B \\
\text { Bacteria } \\
\left(\mu g \mathrm{~N} \mathrm{I}^{-1}\right)\end{array}$ & $\begin{array}{c}A+B) \\
\left(\mu g N^{-1}\right)\end{array}$ & $\begin{array}{c}\text { Total } \\
\left(\mu \mathrm{g} \mathrm{l}^{-1}\right)\end{array}$ & $\begin{array}{c}\text { Detrital nitrogen } \\
\text { Total }-(\mathrm{A}+\mathrm{B}) \\
\left(\mu \mathrm{g} \mathrm{l}^{-1}\right)\end{array}$ \\
\hline \multicolumn{8}{|c|}{ (a) West coast } \\
\hline \multicolumn{8}{|c|}{ Oudekraal } \\
\hline 21. 2. 84 & 14 & $\mathrm{D}$ & 80.9 & 29.8 & 110.7 & 106 & - \\
\hline 22. 2. 84 & 16 & $\mathrm{D}$ & 3.5 & 24.3 & 27.8 & 86 & 58.2 \\
\hline 23. 2.84 & 15.5 & $\mathrm{D}$ & 30.9 & 22.2 & 53.1 & 40 & - \\
\hline 9. 3.84 & 11 & $\mathrm{U}$ & 5.2 & 16.2 & 21.4 & 13 & - \\
\hline \multicolumn{8}{|c|}{ Bloubergstrand } \\
\hline 16. 4.83 & 12.5 & $\mathrm{U}$ & 32.6 & 15.6 & 48.2 & 41 & - \\
\hline 17.4 .83 & 11.5 & $\mathrm{U}$ & 18.6 & 13.4 & 32.0 & 38 & 6 \\
\hline 18.4 .83 & 12 & $\mathrm{U}$ & 13.2 & 15.6 & 28.8 & 34 & 5.2 \\
\hline 19.4 .83 & 10 & $\mathrm{U}$ & 19.1 & 13.4 & 32.5 & 36 & 3.5 \\
\hline 20.4 .83 & 11 & $U$ & 35.2 & 16.1 & 51.3 & 36 & - \\
\hline 22.4 .83 & 13 & $\mathrm{U}$ & 22.5 & 21.0 & 43.5 & 23 & - \\
\hline 20.2 .84 & 15 & $\mathrm{D}$ & 3.6 & 23.5 & 27.1 & 56 & 28.9 \\
\hline 21. 2. 84 & 14.5 & $\mathrm{D}$ & 7.6 & 17.8 & 25.4 & 41 & 15.6 \\
\hline 22.2 .84 & 16 & $\mathrm{D}$ & 42.1 & 16.4 & 58.5 & 60 & 1.5 \\
\hline 6.3 .84 & 16 & $\mathrm{D}$ & 54.1 & 20.5 & 74.6 & 95 & 20.4 \\
\hline 9. 3. 84 & 13 & $\mathrm{U}$ & 10.8 & 21.8 & 32.6 & 110 & 77.4 \\
\hline \multicolumn{8}{|c|}{ (b) East coast } \\
\hline 24. 1. 84 & 21 & - & 11.4 & 19.3 & 30.7 & 11.2 & - \\
\hline 7. 2. 84 & 15 & - & 11.8 & 19.0 & 30.8 & 52.5 & 21.7 \\
\hline 20.2 .84 & 21 & - & 30.5 & 31.9 & 62.4 & 43.0 & - \\
\hline 21. 2. 84 & 19 & - & 0 & 23.9 & 23.9 & 26.0 & 2.1 \\
\hline
\end{tabular}

Table 5. Mean values for carbon and nitrogen resources in phytoplankton, bacteria and detritus in nearshore waters of the Cape Peninsula. Mean values calculated from Tables $3 \& 4$. Data expressed as $\mu g \mathrm{l}^{-1}$

\begin{tabular}{|c|c|c|c|c|c|c|c|c|c|c|}
\hline \multirow[t]{2}{*}{ Site } & \multicolumn{2}{|c|}{ Phytoplankton } & \multicolumn{2}{|c|}{ Bacteria } & \multicolumn{3}{|c|}{ Detritus } & \multicolumn{3}{|c|}{ Total } \\
\hline & $\mathrm{C}$ & $\mathrm{N}$ & C & $N$ & C & $N$ & $\mathrm{C} / \mathrm{N}$ & $\mathrm{C}$ & $N$ & $\mathrm{C} / \mathrm{N}$ \\
\hline \multicolumn{11}{|l|}{ (a) West coast } \\
\hline Upwelling & 129.5 & 19.7 & 58.2 & 15.6 & 124.9 & 11.5 & 10.8 & 307.1 & 46.2 & 6.6 \\
\hline Downwelling & 209.9 & 31.8 & 75.3 & 21.5 & 173.1 & 17.8 & 9.7 & 458.3 & 71.1 & 6.4 \\
\hline \multicolumn{11}{|l|}{ (b) East coast } \\
\hline Bailey's Cottage & 121.7 & 18.4 & 82.3 & 23.5 & 113.4 & 6.0 & 18.9 & 317.4 & 47.9 & 6.6 \\
\hline
\end{tabular}

The black mussel Choromytilus meridionalis is a common inhabitant of the rocky reefs around the Cape Peninsula. The respiration rate of mussels of various shell lengths at $12^{\circ} \mathrm{C}$, representing cooler upwelling waters, and at $18^{\circ} \mathrm{C}$, representing warm downwelling surface water and conditions in False Bay on the east coast, are summarised from Griffiths (1980) in Table 6. The carbon equivalent of oxygen consumption has been calculated from $1 \mu \mathrm{l} 0_{2}=0.536 \mu \mathrm{gC}$ (see also Jørgensen 1955). Griffiths (1980) reported that respiration (R) comprises $74 \%$ of the absorbed ration in $C$. meridionalis, whence the carbon equivalent of the absorbed ration may be estimated from $\mathrm{R} \times 1.351$.
Table 6 lists filtration rates of Choromytilus meridionalis of different sizes at 12 and $18^{\circ} \mathrm{C}$ from Griffiths (1980). The potential carbon yield, assuming that the mussels could exploit phytoplankton, bacteria and detrital components with equal efficiency, is therefore obtained from the product of the concentration of each resource ( $\mu \mathrm{g} \mathrm{l}^{-1}$; see also Table 5) and the filtration rate $\left(V_{w}, 1 h^{-1}\right)$. Comparison of the carbon demand for each size class under upwelling $\left(12^{\circ} \mathrm{C}\right)$ and downwelling $\left(18^{\circ} \mathrm{C}\right)$ conditions with the potential yield from filtration shown in Table 7 gives some indication of the extent to which phytoplankton, bacterial and detrital resources are potentially available to 
Table 6. Choromytilus meridionalis. Estimated carbon consumption requirements in relation to body size (shell length, mm) at $12^{\circ} \mathrm{C}$ (= upwelling) and $18^{\circ} \mathrm{C}(=$ downwelling and east coast water). Oxygen consumption calculated from Griffiths (1980). carbon equivalent from $1 \mu \mathrm{l} \mathrm{O}=0.536 \mu \mathrm{g} \mathrm{C}$. Respiration has been found to equal a mean value of $0.74 \times$ absorbed ration $(\mathrm{A})$, whence $\mathrm{A}=\mathrm{R} \times 1.351$

\begin{tabular}{|c|c|c|c|c|c|c|}
\hline \multirow[b]{2}{*}{$\begin{array}{l}\text { Shell } \\
\text { length } \\
(\mathrm{mm})\end{array}$} & \multirow[b]{2}{*}{$\begin{array}{c}\text { Oxygen } \\
\text { consumption } \\
\left.(\mu\rfloor \mathrm{h}^{-1}\right)\end{array}$} & \multirow{2}{*}{$\begin{array}{l}\mathrm{T}=\mathbf{1 2} \mathbf{2}^{\circ} \mathrm{C} \\
\text { Carbon } \\
\text { equivalent } \\
\text { (ug } \mathrm{C} \mathrm{h}^{-1} \text { ) }\end{array}$} & \multicolumn{4}{|c|}{$\mathrm{T}=18^{\circ} \mathrm{C}$} \\
\hline & & & $\begin{array}{l}\text { Absorption } \\
\text { requirements } \\
\text { ( } \mu \mathrm{g} \mathrm{C} \mathrm{h}^{-1} \text { ) }\end{array}$ & $\begin{array}{c}\text { Oxygen } \\
\text { consumption } \\
\left(\mu l \mathrm{~h}^{-1}\right)\end{array}$ & $\begin{array}{l}\text { Carbon } \\
\text { equivalent } \\
\left(\mu \mathrm{g} \mathrm{C} \mathrm{h}^{-1}\right)\end{array}$ & $\begin{array}{l}\text { Absorption } \\
\text { requirement } \\
\left(\mu \mathrm{g} \mathrm{C} \mathrm{h}^{-1}\right)\end{array}$ \\
\hline 20 & 43 & 23 & 31 & 65 & 35 & 47 \\
\hline 40 & 155 & 83 & 112 & 220 & 118 & 159 \\
\hline 60 & 280 & 150 & 203 & 390 & 209 & 282 \\
\hline 80 & 490 & 263 & 355 & 670 & 359 & 485 \\
\hline 100 & 700 & 375 & 507 & 1000 & 536 & 724 \\
\hline
\end{tabular}

Table 7. Choromytilus meridionalis. Potential carbon yield from phytoplankton, bacteria and detritus for mussels of different sizes under upwelling and downwelling conditions on the west coast of the Cape Peninsula and in False Bay on the east coast. Values calculated from the product of filtration rate of different-sized mussels $\left(\mathrm{V}_{\mathrm{w}}, \mathrm{l} \mathrm{h}^{-1}\right)$ at $12^{\circ} \mathrm{C}$ recalculated from Griffiths

(1980), assuming $100 \%$ retention efficiency and mean concentration for each resource in the water column (see Table 3 )

\begin{tabular}{|c|c|c|c|c|c|c|}
\hline & \multicolumn{6}{|c|}{ Shell length $(\mathrm{mm})$} \\
\hline & & 20 & 40 & 60 & 80 & 100 \\
\hline & \multicolumn{6}{|c|}{ Filtration rate $V_{W}\left(1 h^{-1}\right)$} \\
\hline & $12^{\circ} \mathrm{C}:$ & 0.64 & 1.80 & 3.20 & 4.80 & 6.50 \\
\hline & $18^{\circ} \mathrm{C}$ & 0.64 & 1.90 & 3.80 & 5.50 & 7.70 \\
\hline \multirow[t]{2}{*}{ Condition } & \multirow{2}{*}{$\begin{array}{l}\text { Carbon } \\
\text { resource } \\
\left(\mu g \mathrm{C}^{-1}\right)\end{array}$} & \multicolumn{5}{|c|}{$\begin{array}{l}\text { Carbon yield } \\
\left(\mu \mathrm{g} \mathrm{C} \mathrm{h} \mathrm{h}^{-1}\right)\end{array}$} \\
\hline & & 20 & 40 & 60 & 80 & 100 \\
\hline \multicolumn{7}{|l|}{$\begin{array}{l}\text { (a) West coast } \\
\text { Upwelling }\left(12^{\circ} \mathrm{C}\right)\end{array}$} \\
\hline Phytoplankton & 129.5 & 82.8 & 233.1 & 414.4 & 621.1 & 841.7 \\
\hline Bacteria & 58.2 & 37.2 & 104.7 & 186.2 & 279.4 & 378.3 \\
\hline Detritus & 124.9 & 79.9 & 224.8 & 399.7 & 599.5 & 811.9 \\
\hline \multicolumn{7}{|l|}{ Downwelling $\left(18^{\circ} \mathrm{C}\right)$} \\
\hline Phytoplankton & 209.9 & 134.3 & 398.8 & 797.6 & 1154.5 & 1616.2 \\
\hline Bacteria & 75.3 & 48.2 & 143.1 & 286.1 & 414.2 & 579.8 \\
\hline Detritus & 173.1 & 110.8 & 328.9 & 657.8 & 952.1 & 1332.9 \\
\hline \multicolumn{7}{|l|}{ (b) East coast } \\
\hline \multicolumn{7}{|c|}{ Bailey's Cottage $\left(18^{\circ} \mathrm{C}\right)$} \\
\hline Phytoplankton & 121.7 & 77.9 & 231.2 & 462.5 & 584.2 & 791.1 \\
\hline Bacteria & 82.2 & 52.6 & 156.1 & 312.4 & 452.1 & 632.9 \\
\hline Detritus & 113.4 & 72.6 & 215.5 & 430.9 & 623.7 & 873.2 \\
\hline
\end{tabular}

meet the consumption requirements of this common filter-feeding bivalve.

It can be seen that at $12^{\circ} \mathrm{C}$ a small mussel of $20 \mathrm{~mm}$ shell length requires $31 \mu \mathrm{g} \mathrm{Ch}^{-1}$, rising to $507 \mu \mathrm{g} \mathrm{Ch}^{-1}$ for a large specimen of $100 \mathrm{~mm}$ shell length. This carbon demand could not be met by the phytoplankton even when assuming $100 \%$ retention efficiency (Table 7) when phytoplankton falls below average concentrations. But it could be met by combined exploitation of phytoplankton and detritus, or by utilisation of some bacterial component. It is clear, therefore, that this bivalve must exploit more resources than just the phytoplankton to meet its carbon demands, when phytoplankton falls below average concentrations (Table 1).

Under downwelling conditions at $18^{\circ} \mathrm{C}$, carbon absorption requirements range from $47 \mu \mathrm{g} \mathrm{h}^{-1}$ for a small mussel of $20 \mathrm{~mm}$ shell length, to $724 \mu_{\mathrm{g} \mathrm{h}}^{-1}$ for a larger specimen of $100 \mathrm{~mm}$ shell length (Table 6). These demands could be met by the average phytoplankton carbon availability (Table 5) but the discrepancy is so great at other times (see Table 1) that almost half the carbon supply must be derived from a 
Table 8. Choromytilus meridionalis. Estimated nitrogen requirements ( $\mu \mathrm{g} \mathrm{N} \mathrm{h} \mathrm{h}^{-1}$ ) at $12^{\circ} \mathrm{C}$ (upwelling conditions) and $18^{\circ} \mathrm{C}$ (west coast population under downwelling conditions, and east coast population). Values calculated from oxygen consumption as $\mu \mathrm{g}$ $\mathrm{h}^{-1}$ in relation to size (Table 5). Nitrogen ingestion requirements estimated from values for ammonia nitrogen excretion $\times 1.3$ (see Hawkins 1983 and Table 5). Ammonia excretion values calculated from a maximum $O: N$ ratio of 108, mean value of 46.4, and a minimum value of 11.0 for Mytilus edulis (Hawkins 1983). Maximum values for nitrogen requirement accord well with estimates based on oxygen consumption, absorbed ration and C : N ratio of mussel tissue (Seiderer et al. 1984)

\begin{tabular}{|c|c|c|c|c|c|}
\hline \multirow{2}{*}{$\begin{array}{l}\text { Choromytilus meridionalis } \\
\text { Nitrogen requirements }\end{array}$} & \multirow[b]{2}{*}{20} & \multicolumn{4}{|c|}{ Shell length (mm) } \\
\hline & & 40 & 60 & 80 & 100 \\
\hline \multicolumn{6}{|l|}{$\mathrm{T}=12^{\circ} \mathrm{C}$} \\
\hline Oxygen consumption $\left(\mu \mathrm{g} \mathrm{h}^{-1}\right)$ & 31 & 111 & 200 & 350 & 500 \\
\hline \multicolumn{6}{|l|}{ Nitrogen ingestion requirements } \\
\hline Maximum $(\mathrm{O}: \mathrm{N}$ ratio 11$)$ & 2.8 & 10.0 & 18.2 & 31.8 & 45.5 \\
\hline Mean $(\mathrm{O}: \mathrm{N}$ ratio 46.4$)$ & 0.7 & 2.4 & 4.3 & 7.5 & 10.8 \\
\hline Minimum $(\mathrm{O}: \mathrm{N}$ ratio 108$)$ & 0.3 & 1.0 & 1.9 & 3.2 & 4.6 \\
\hline \multicolumn{6}{|l|}{$\mathrm{T}=18^{\circ} \mathrm{C}$} \\
\hline Oxygen consumption $\left(\mu \mathrm{g} \mathrm{h}^{-1}\right)$ & 46 & 157 & 279 & 478 & 714 \\
\hline \multicolumn{6}{|l|}{ Nitrogen ingestion requirements } \\
\hline Maximum $(\mathrm{O}: \mathrm{N}$ ratio 11$)$ & 4.2 & 14.3 & 25.4 & 43.5 & 64.9 \\
\hline Mean $(O: N$ ratio 46.4$)$ & 1.0 & 3.4 & 6.0 & 10.3 & 15.4 \\
\hline Minimum $(\mathrm{O}: \mathrm{N}$ ratio 108$)$ & 0.4 & 1.5 & 2.6 & 4.4 & 6.6 \\
\hline
\end{tabular}

resource other than the phytoplankton. Even assuming $100 \%$ retention efficiency for both phytoplankton and bacteria, the mussels would still require intensive utilisation of the detrital pool to meet their estimated demand at $18^{\circ} \mathrm{C}$.

\section{Nitrogen requirements in relation to potential yield}

Estimated nitrogen requirements of Choromytilus meridionalis at $12{ }^{\circ} \mathrm{C}$ (upwelling conditions) and $18^{\circ} \mathrm{C}$ (downwelling conditions and east coast populations) are summarised in Table 8 . Oxygen consumption in relation to body size is recalculated from Griffiths (1980) as $\mu \mathrm{g} \mathrm{h}^{-1}$ (see also Table 6). Hawkins (1983) has shown that in the mussel Mytilus edulis, nitrogen losses vary considerably on a seasonal basis, the $\mathrm{O}: \mathrm{N}$ ratio varying from 11 to as high as 108 with a mean of 46.4 . Nitrogen ingestion requirements can be estimated from the values for ammonia excretion x 1.3 (Hawkins 1983). We have calculated a maximum, minimum and mean nitrogen ingestion requirement from the excretion values based on each of the $O: N$ ratios; these are summarised in Table 8.

The maximum nitrogen demand of Choromytilus meridionalis is likely to vary between $2.8 \mu \mathrm{g} \mathrm{h}^{-1}$ for small specimens of $20 \mathrm{~mm}$ shell length, to $45.5 \mu \mathrm{g} \mathrm{h}^{-1}$ for large mussels of $100 \mathrm{~mm}$ shell length under upwelling conditions. Comparable maximal values for nitrogen demand at $18{ }^{\circ} \mathrm{C}$ are $4.2 \mu \mathrm{g} \mathrm{h}^{-1}$ for a $20 \mathrm{~mm}$ shell length mussel, increasing to $64.9 \mu \mathrm{g} \mathrm{h}^{-1}$ for large mussels of $100 \mathrm{~mm}$ shell length. Mean values for nitro- gen demand, however, vary from 0.7 to $10.8 \mu \mathrm{g} \mathrm{h}^{-1}$ at $12{ }^{\circ} \mathrm{C}$ to 1.0 to $15.4 \mu \mathrm{g} \mathrm{h}^{-1}$ at $18^{\circ} \mathrm{C}$.

Table 9 shows the filtration rate at 12 and $18^{\circ} \mathrm{C}$ for Choromytilus meridionalis of shell length from 20 to $100 \mathrm{~mm}$ (after Griffiths 1980). The nitrogen yield, as in the case of the carbon yield shown in Table 7, has been obtained from the product of filtration rate and mean resource availability (Table 5 ) assuming $100 \%$ retention efficiency. It is clear that at $12{ }^{\circ} \mathrm{C}$ the maximum nitrogen demand of 2.8 to $45.5 \mu \mathrm{g} \mathrm{h}^{-1}$ could be met from the phytoplankton alone which could supply 12.5 to $127.4 \mu \mathrm{g} \mathrm{N} \mathrm{h}^{-1}$. Bacteria, if the mussels were capable of retention, could also meet the whole nitrogen demands of all except the larger specimens although the detrital supply could meet only somewhat over $50 \%$ of the maximum nitrogen demands. In fact, Stuart \& Klumpp (1984) have recently shown that particles in the bacterial size range are retained with a very low efficiency by Choromytilus meridionalis which therefore appears to be adapted to, and can be supported by, exploitation of the phytoplankton as a nitrogen resource.

Under downwelling conditions at $18^{\circ} \mathrm{C}$ the maximum nitrogen demands of 4.2 to $64.9 \mu \mathrm{g} \mathrm{h}^{-1}$ according to shell size could also be met by the phytoplankton and substantially so on the east coast site at Bailey's Cottage. Utilisation of bacteria alone, if the mussels were capable of bacterial retention, could also wholly satisfy the estimated nitrogen requirements of the mussels, but for the reasons mentioned above, these are unlikely to be exploited by Choromytilus meridionalis. Because the detrital supply under downwelling condi- 
Table 9. Choromytilus meridionalis. Potential nitrogen yield from phytoplankton, bacteria and detritus by mussels of different sizes under upwelling and downwelling conditions on the west coast of the Cape Peninsula and in False Bay on the east coast. Values calculated from the product of filtration rate of different-sized mussels $\left(\mathrm{V}_{\mathrm{w}}, \mathrm{l} \mathrm{h}^{-1}\right)$ at $12^{\circ} \mathrm{C}$ and $18^{\circ} \mathrm{C}$ recalculated from Griffiths (1980) assuming $100 \%$ retention efficiency and the mean concentration of each resource in the water column (see Table 4 )

\begin{tabular}{|c|c|c|c|c|c|c|}
\hline & \multicolumn{6}{|c|}{ Shell length (mm) } \\
\hline & & 20 & 40 & 60 & 80 & 100 \\
\hline & \multicolumn{6}{|c|}{ Filtration rate $V_{W}\left(1 \mathrm{~h}^{-1}\right)$} \\
\hline & $12^{\circ} \mathrm{C}:$ & 0.64 & 1.80 & 3.20 & 4.80 & 6.50 \\
\hline & $18^{\circ} \mathrm{C}:$ & 0.64 & 1.90 & 3.80 & 5.50 & 7.70 \\
\hline \multirow[t]{2}{*}{ Condition } & \multirow{2}{*}{$\begin{array}{l}\text { Nitrogen } \\
\text { resource } \\
\left(\mu g \mathrm{~N} \mathrm{l}^{-1}\right)\end{array}$} & \multicolumn{4}{|c|}{$\begin{array}{l}\text { Nitrogen yield } \\
\quad\left(\mu \mathrm{g} \mathrm{N} \mathrm{h}^{-1}\right)\end{array}$} & \\
\hline & & 20 & 40 & 60 & 80 & 100 \\
\hline \multicolumn{7}{|l|}{ (a) West coast } \\
\hline \multicolumn{7}{|l|}{ Upwelling $\left(12^{\circ} \mathrm{C}\right)$} \\
\hline Phytoplankton & 19.6 & 12.5 & 35.3 & 62.7 & 94.1 & 127.4 \\
\hline Bacteria & 15.6 & 9.9 & 28.1 & 49.7 & 74.9 & 101.4 \\
\hline Detritus & 11.5 & 7.4 & 20.7 & 36.8 & 55.2 & 74.8 \\
\hline \multicolumn{7}{|c|}{ Downwelling $\left(18^{\circ} \mathrm{C}\right)$} \\
\hline Phytoplankton & 31.8 & 20.4 & 60.4 & 120.8 & 174.9 & 244.9 \\
\hline Bacteria & 21.5 & 13.8 & 40.9 & 81.7 & 118.3 & 165.6 \\
\hline Detritus & 17.8 & 11.4 & 33.8 & 67.6 & 97.9 & 137.1 \\
\hline \multicolumn{7}{|l|}{ (b) East coast } \\
\hline \multicolumn{7}{|c|}{ Baileys Cottage $\left(18^{\circ} \mathrm{C}\right)$} \\
\hline Phytoplankton & 18.4 & 11.8 & 34.9 & 69.9 & 101.2 & 141.7 \\
\hline Bacteria & 23.5 & 15.0 & 44.7 & 89.3 & 129.3 & 181.0 \\
\hline Detritus & 5.95 & 3.8 & 11.3 & 22.6 & 32.7 & 45.8 \\
\hline
\end{tabular}

tions has a higher nitrogen content than under upwelling conditions (p. 132) its potential contribution to the nitrogen budget of consumers is almost as important as that of the bacteria. On the warmer east coast at Bailey's Cottage, however, the detrital resource could contribute only $25 \%$ of the nitrogen demand even at $100 \%$ retention efficiency, although in this case the bacterial nitrogen resource is of dominant importance and exceeds even that of the phytoplankton for consumers which are capable of utilising particles in this size range.

\section{DISCUSSION}

Our results confirm and extend previous studies on the relative importance of the standing stocks of phytoplankton and bacteria in nearshore waters (Ferguson \& Rublee 1976, Mazure \& Field 1980, Linley \& Field 1982). The standing stocks of phytoplankton on the west coast of the Cape Peninsula, South Africa, show marked short-term variations, reaching maximal values in this study of $8.9 \mu \mathrm{g}$ chlorophyll $\mathrm{al}^{-1}$ at the end of a downwelling phase when warm surface water of approximately $16^{\circ} \mathrm{C}$ impinges on the coast. Following a period of south-east winds, cold water of $11^{\circ} \mathrm{C}$ or less upwells in the nearshore waters (Andrews \& Hutchings
1980, Field et al. 1980) and the chlorophyll a concentrations may fall, within $24 \mathrm{~h}$, to $0.6 \mu \mathrm{g} \mathrm{l} \mathrm{l}^{-1}$ or less. At the same time, the standing stocks of bacteria which we recorded are relatively high, ranging from a

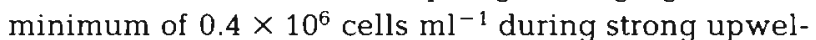
ling pulses to a maximum of $5.9 \times 10^{6}$ cells ml-1 during downwelling phases.

The carbon supply in the water column generally

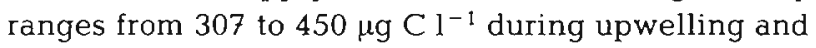
downwelling phases with an associated nitrogen variation of 46 to $71.1 \mu \mathrm{g} \mathrm{N}^{-1}$. Comparison of the relative allocation of carbon resources between phytoplankton, bacteria and detrital pools shows that towards the end of a downwelling phase, when phytoplankton is at its maximum, the carbon represented by phytoplankton generally amounts to $>50 \%$ of the total particulate carbon in the water column, and may dominate the resource as a whole. The bacteria, however, represent a carbon resource which is of similar importance to the detrital component, especially during downwelling phases.

During periods of relatively weak upwelling, for example, bacterial numbers range from 2.3 to $3.6 \times 10^{6}$ cells $\mathrm{ml}^{-1}$ which corresponds with a bacterial carbon pool of 47 to $73 \mu \mathrm{g}^{-1}$. The detrital supply simultaneously ranged from 47 to $50.5 \mu \mathrm{g} \mathrm{l}^{-1}$ whilst the phyto- 
plankton accounted for 87 to $232 \mu \mathrm{g} \mathrm{C} \mathrm{l}^{-1}$ and was therefore 2 to 3 times $x$ that of the carbon in the bacterial or detrital components.

Because of their relatively low $\mathrm{C}: \mathrm{N}$ ratio of 3.5 to 3.7 compared with 6.6 for phytoplankton, however, bacteria represent a nitrogen resource which is relatively important compared with the phytoplankton, especially during upwelling phases. In contrast, the nitrogen content of the detrital supply is generally low with the $\mathrm{C}: \mathrm{N}$ ratio reaching 18.9 during upwelling phases (Table 5). The detrital pool is thus likely to represent a relatively poor nitrogen resource for filter-feeding animals compared with bacteria and phytoplankton.

Estimates of the carbon consumption requirements of the black mussel Choromytilus meridionalis suggest that during cold upwelling conditions at $12{ }^{\circ} \mathrm{C}$ a small mussel of $20 \mathrm{~mm}$ shell length would require $31 \mu \mathrm{g} \mathrm{C}$ $\mathrm{h}^{-1}$, rising to $507 \mu \mathrm{g} \mathrm{C} \mathrm{h}{ }^{-1}$ for a larger specimen of $100 \mathrm{~mm}$ shell length (Table 6). Again, under downwelling conditions, carbon consumption requirements for a small mussel of $20 \mathrm{~mm}$ shell length at $18^{\circ} \mathrm{C}$ would be $47 \mu \mathrm{g} \mathrm{C} \mathrm{h}{ }^{-1}$, increasing to $724 \mu \mathrm{g} \mathrm{C} \mathrm{h}^{-1}$ for a larger mussel of $100 \mathrm{~mm}$ shell length. Neither of these demands could be met when phytoplankton carbon availability falls below average; even if both phytoplankton and bacteria were retained, the mussel would still need a major detritus supply to meet its carbon requirements from the resources available in the water column. It is of interest, therefore, that recent studies on the digestive physiology of $C$. meridionalis suggest that it has carbohydrases capable of exploiting detritus as a carbon resource (Seiderer et al. 1982). Again, the ribbed mussel Aulacomya ater, which is also common in kelp communities, is capable of absorbing kelp detritus with an efficiency comparable to that of phytoplankton (Stuart et al. 1982).

In contrast, the estimated nitrogen demand of 2.8 to $45.5 \mu \mathrm{g} \mathrm{N} \mathrm{h}^{-1}$ at $12{ }^{\circ} \mathrm{C}$ depending on shell length, could be obtained from the phytoplankton alone which could supply 12.5 to $127.4 \mu \mathrm{g} \mathrm{N} \mathrm{h}^{-1}$ at $100 \%$ retention efficiency. The detrital supply could, however, meet only 25 to $50 \%$ of the estimated nitrogen requirements of the mussels under upwelling conditions.

The detrital component in the water column thus appears to represent an important carbon resource for Choromytilus meridionalis whose carbon demands cannot be met by utilising phytoplankton alone, even at $100 \%$ retention efficiency. Phytoplankton however, can meet the nitrogen requirements of the mussel which does not, therefore, appear to require bacteria to cover its nutritional requirements, unless the phytoplankton falls below average concentrations. In such a case, bacteriolytic lysozyme-like enzymes in the crystalline style may attain some significance (Seiderer et al. 1984), although the low retention efficiency of bac- teria sized particles (Stuart \& Klumpp 1984) suggests that bacterial aggregates rather than free-living forms would then be utilised.

Bacteria remain a resource of comparable importance to the phytoplankton as a nitrogen pool during upwelling phases. They are thus likely to be of major significance to those filter-feeders - including bivalves (Wright et al. 1982) and dense communities of sponges and ascidians - which characterise kelp-bed communities (Velimirov et al. 1977) and which are capable of exploiting particles in the bacterial size range.

Acknowledgements. We thank Mr Peter Fielding and Mrs Sandy Tolosana, both of the University of Cape Town. This work was supported mainly by funds from the Benguela Ecology Programme of the South African National Committee for Oceanographic Research.

\section{LITERATURE CITED}

Andrews, W. R. H., Hutchings, L. (1980). Upwelling in the Southern Benguela current. Prog. Oceanogr. 9: 1-81

Baker, J. H., Bradnam, L. A. (1976). The role of bacteria in the nutrition of aquatic detritivores. Oecologia (Berl.) 24: 95-104

Barlow, R. G. (1982): Phytoplankton ecology in the Southern Benguela current. III. Dynamics of a bloom. J. exp. mar. Biol. Ecol. 63: 239-248

Brown, P. C. (1981). Pelagic phytoplankton, primary production, and nutrient supply in the Southem Benguela region. Trans. R. Soc. S. Afr, 44: 347-356

Cammen, L. M. (1977). On the use of liquid scintillation counting of ${ }^{51} \mathrm{Cr}$ and ${ }^{14} \mathrm{C}$ in the twin tracer method of measuring assimilation efficiency. Oecologia (Berl.) 30 (3) : 249-252

Cammen, L. M. (1980a). Ingestion rate: an empirical model for aquatic deposit feeders and detritivores. Oecologia (Berl.) 44: 303-310

Cammen, L. M. (1980b). The significance of microbial carbon in the nutrition of the deposit feeding polychaete Nereis succinea. Mar. Biol. 61: 9-20

Carter, R. A. (1982). Plankton biomass and production in a southern Benguela kelp bed system. Mar. Ecol. Prog. Ser. 8: 9-14

Claus, G., Madri, P. P., Kunen, S. M. (1967), Removal of microbial pollutants from waste effluents by the redbeard sponge. Nature, Lond. 216: 712-714

Cliff, G. (1982). Seasonal variation in the contribution of phytoplankton, bacteria, detritus and inorganic nutrients to a rocky shore ecosystem. Trans. R. Soc. S. Afr. 44: 523-538

Daley, R. J. (1979). Direct epifluorescence enumeration of native aquatic bacteria: uses, limitations and comparative accuracy. In: Costerton, J. W., Colwell, R. R. (ed.) Natural aquatic bacteria: enumeration, activity and ecology. Am. Soc. Test. Materials, Philadeliphia, p. 29-45

Elyakova, L. A. (1972): Distribution of cellulases and chitinases in marine invertebrates. Comp. Biochem. Physiol. 43B: $67-70$

Ferguson, R. L., Rublee, P. (1976). Contribution of bacteria to the standing crop of coastal plankton. Limnol. Oceanogr. 21: $141-145$

Field, J. G. (1983). Coastal ecosytems: flow patterns of energy 
and matter. In: Kinne. O. (ed.) Marine ecology, Vol. V, Ocean management. Wiley, Chichester, p. 758-794

Field, J. G., Jarman, N. G., Dieckmann, G. S., Griffiths, C. L., Velimirov, B., Zoutendyk, P. (1977). Sun, waves, seaweed and lobsters: the dynamics of a west coast kelp bed. S. Afr. J. Sci. 73: 7-10

Field, J. G., Griffiths, C. L., Linley, E. A., Carter, R. A., Zoutendyk, P. (1980). Upwelling in a nearshore marine ecosystem and its biological implications. Estuar. coast. mar. Sci. 11: 133-150

Frost, T. M. (1978). In situ measurements of clearance rates for the freshwater sponge Spongilla lacustris. Limnol. Oceanogr. 23: 1034-1039

Griffiths, R. J. (1980). Filtration, respiration and assimilation in the black mussel Choromytilus meridionalis. Mar. Ecol. Prog. Ser. 3: 63-70

Hagström, A., Larsson, V., Hörstedt, P., Normark, S. (1979). Frequency of dividing cells, a new approach to the determination of bacterial growth rates in aquatic envrionments. Appl. environ. Microbiol. 37: 805-812

Harbison, G. R., McAlister, V. L. (1979). The filter-feeding rates and particle retention efficiencies of three species of Cyclosalpa (Tunicata, Thaliacea). Limnol. Oceanogr. 24: 875-892

Hawkins, A. J. S. (1983). Metabolic strategy in the marine mussel, Mytilus edulis L. Ph. D. thesis, University of Exeter

Hobbie, J. E., Daley, R. T., Jasper, S. (1977). Use of Nuclepore filters for counting bacteria by fluorescence microscopy, App. environ. Microbiol. 33: 1225-1228

Jeffrey, S. W., Humphrey, G. F. (1975). New spectrophotometric equations for determining clorophylls $a, b, C$ and $D_{2}$ in higher plants, algae and natural phytoplankton. Biochem. Physiol. Pflanzen 167: 191-194

Jensen, K. T., Siegismund, M. R. (1980). The importance of diatoms and bacteria in the diet of Hydrobia species. Ophelia 19 (Suppl.): 193-199

Jørgensen, C. B. (1955). Quantitative aspects of filter-feeding in invertebrates. Biol. Rev. 30: 391-454

Jørgensen, C. B. (1975). Comparative physiology of suspension feeding. A. Rev. Physiol. 37: 57-79

Kirby-Smith, W. W. (1976). The detritus problem and the feeding and digestion of an estuarine organism. In: Wiley, M. (ed.) Estuarine processes, Vol. 1. Academic Press, New York, p. 469-479

Kristensen, J. H. (1972). Carbohydrases of some marine invertebrates with notes on their food and on the natural occurrence of the carbohydrates studied. Mar. Biol, 14: $130-142$

Linley, E. A. S. (1983). The role of micro-organisms in the decomposition of plant detritus in the sea. Ph. D. thesis, University Exeter

Linley, E. A. S., Newell, R. C., Bosma, S. A. (1981). Heterotrophic utilisation of mucilage released during fragmentation of kelp (Ecklonia maxima and Laminaria pallida). I. Development of microbial communities associated with the degradation of kelp mucilage. Mar. Ecol. Prog. Ser. 4: $31-41$

Linley, E. A. S., Field, J. G. (1982). The nature and ecological significance of bacterial aggregation in west-coast kelp beds. Estuar coast. Shelf Sci. 14: 1-11

Linley, E. A. S., Newell, R. C., Lucas, M. I. (1983). Quantitative relationships between phytoplankton, bacteria and heterotrophic microflagellates in shelf waters. Mar. Ecol. Prog. Ser, 12: 77-89

Lucas, M. I., Newell, R. C. (1984). Utilisation of saltmarsh grass detritus by the oyster Crassostrea virginica and the mussel Geukensia demissa: Carbohydrase activity of the crystalline style enzymes in relation to carbon requirements. Mar. Biol. Lett. 5: 275-290

Luria, S. E. (1960). The bacterial protoplasm: composition and organisation. In: Gunsalus, I. C., Stanier, R. K. (ed.) The bacteria, Vol. 1 Academic Press, New York, p. 1-34

Mazure, H. G. F. (1978). The seasonal cycle of marine bacteria in a west coast kelp-bed. Trans. R. Soc. Afr. 43: 119-124

Mazure, H. G. F., Field, J. G. (1980). Density and ecological importance of bacteria on kelp fronds in an upwelling region. J. exp. mar. Biol. Ecol. 43: 173-182

Møhlenberg, F., Riisgård, H. V. (1978). Efficiency of particle retention in 13 species of suspension feeding bivalves. Ophelia 17: $239-246$

Monar, I. (1972). Analysenautomat zur simultanen Mikrobestimmung von $\mathrm{C}, \mathrm{H}$ und $\mathrm{N}$. Mikrochim. Acta 1972: $784-806$

Newell, R. C. (1984). The biological role of detritus in the marine environment. In: Fasham, M. J. R. (ed.) Flows of energy and materials in marine ecosystems. Plenum Publishing Corporation, New York, p. 317-343

Newell, R. C., Field, J. G., Griffiths, C. L. (1982). Energy balance and significance of micro-organisms in a kelp bed community. Mar. Ecol. Prog. Ser. 8: 103-113

Newell, R. C., Field, J. G. (1983a). The contribution of bacteria and detritus to carbon and nitrogen flow in a benthic community. Mar, Biol. Lett. 4: 23-36

Newell, R. C., Field, J. G. (1983b). Relative flux of carbon and nitrogen in a kelp-dominated system. Mar. Biol. Lett. 4: 249-257

Randløv, A., Riisgård, H. V. (1979). Efficiency of particle retention and filtration rate in four species of ascidians. Mar. Ecol. Prog. Ser. 1: 55-59

Reiswig, H. M. (1971). Particle feeding in natural populations of three marine demosponges. Biol. Bull. mar. biol. Lab., Woods Hole 141: 568-591

Reiswig, H. M. (1975). Bacteria as food for temperate-water marine sponges. Can. J. Zool. 53: 582-589

Seiderer, L. J. (1983). The physiology of digestion in marine mussels: a study in environmental adaptation. Ph. D. thesis, University of Cape Town

Seiderer, L. J., Newell, R. C., Cook, P. A. (1982). Quantitative significance of style enzymes from two marine mussels (Choromytilus meridionalis Krauss and Perna perna Linnaeus) in relation to diet. Mar. Biol. Lett. 3: 257-271

Seiderer, L. J, Davis, C. L., Robb, F. T., Newell, R. C. (1984). Utilisation of bacteria as a nitrogen resource by kelp bed mussel Choromytilus meridionalis. Mar. Ecol. Prog. Ser. 15: 109-116

Sorokin, Y. I. (1973). Trophical role of bacteria in the ecosysten of the coral reef. Nature, Lond. 242: 415-417

Strickland, J. D. H. (1972). Research on the marine plankton food web at the Institute of Marine Resources: a review of the past seven years work. Oceanogr. mar. biol. A. Rev. 10: $349-414$

Strugger, S. (1949). Fluorescent microscope examination of bacteria in soil. Can. J. Res. 26: 288-294

Stuart, V., Field, J. G., Newell, R. C. (1982). Evidence for the absorption of kelp detritus by the ribbed mussel, Aulacomya ater (Molina) using a new ${ }^{51} \mathrm{Cr}$-labelled microsphere technique. Mar. Ecol. Prog. Ser. 9; 263-271

Stuart, V., Klumpp, D. W. (1984). Evidence for food-resource partitioning by kelp-bed filter feeders. Mar. Ecol. Prog Ser. 16: 27-37

Troitsky, A. S., Sorokin, Y. I. (1967). On the methods of calculation of the bacterial biomass in water bodies. 
Trans. Inst. biol. Inland Waters. Acad. Sci. U. S. S. R. 19: $85-90$

Velimirov, B., Field, J. G., Griffiths, C. L., Zoutendyk, P. (1977). The ecology of kelp communities in the Benguela system. Analysis of biomass and spatial distribution. Helgoländer wiss. Meeresunters. 30: 495-518

Wetzel, R. L. (1976). Carbon resources of a benthic salt-marsh invertebrate, Nassarius obsoletus Say (Mollusca; Nassariidae). In: Wiley, M. (ed.) Estuarine processes, Vol. 2. Academic Press, New York, p. 293-308

Wright, R. T., Coffin, R. B., Ersing, C. P., Pearson, D. (1982). Field and laboratory measurements of bivalve filtration of natural marine bacterioplankton. Limnol. Oceanogr. 27 (1): 91-98
Wulff, F. V., Field, J. G. (1983). The importance of different trophic pathways in a nearhore benthic community under upwelling and downwelling conditions. Mar. Ecol. Prog. Ser. 12: $217-228$

Zimmermann, R., Meyer-Riel, L.-A. (1974). A new method for fluorescence staining of bacterial populations on membrane filters. Kieler Meeresforsch. 30: 24-27

Zimmermann, R. (1977). Estimation of bacterial numbers and biomass by epifluorescence microscopy and scanning electron microscopy. In: Rheinheimer, G. (ed.) Microbial ecology of a brackish water environment. Springer-Verlag, Berlin, p. 103-120

This paper was submitted to the editor; it was accepted for printing on December 10, 1984 